Article

\title{
Bioethics and Human Rights in the Constitutional Formation of Global Health
}

\author{
Atina Krajewska
}

Sheffield Law School, University of Sheffield, Bartolomé House, Winter Street, Sheffield, South Yorkshire S3 7ND, UK; E-Mail: a.krajewska@sheffield.ac.uk; Tel.:+44-0-114-222-6879

Academic Editor: Aurora Plomer

Received: 24 September 2015 / Accepted: 14 December 2015 / Published: 18 December 2015

\begin{abstract}
Global health" is an increasingly important area of research and practice, concerned with the profound implications of globalisation for individual and communal health (particularly in developing countries) and focused on achieving health equity for all people worldwide. As such, it is often viewed as overlapping with public health and, thus, conceptually distinct from the field of biomedicine and bioethics. Both fields bear an uneasy relationship with the field of human rights, which remains largely unexplored. The paper constructively utilises insight derived from theories of global legal pluralism and global constitutionalism to argue, perhaps controversially, that recent developments in international biomedical law and bioethics, constitute an important phase in the constitutional construction of a global health law system. In doing so, the paper analyses the role of human rights in the growing constitutional autonomy and organization of global health.
\end{abstract}

Keywords: global health; international law; transnational law; WHO; constitution

\section{Introduction}

This paper aims to provide a novel conceptual framework for examining recent developments in global health law and for analysing the notion of a global health constitution. It contributes to increasingly prominent debates regarding post-traditional patterns of constitutional organisation, often bearing diversely on distinct legal spheres including discussions in public international law, medical- and public health law, and the sociology of law. Global health is understood broadly as "a field of [medical, cultural, and normative] practice, research and education focussed on health and the social, economic, political and cultural forces that shape it across the world...[and a] discipline (...) concerned with 
health-related issues that transcend national boundaries and the differential impacts of globalisation" [1]. Despite an easily observed institutional and normative distinction between public health and medicine [2], as far as this paper is concerned, "global health" includes issues that directly or indirectly affect both health promotion in populations and clinical care and treatment of individuals [3]. Consequently, global health governance (GHG) describes "the use of formal and informal institutions, rules, and processes by states, intergovernmental organisations, and non-state actors to deal with challenges to health that require cross-border collective action" [4]. Governance activities involve substantive goals-ends the societies want to achieve - and procedural mechanisms - how the societies organize the pursuit of their goals. The substantive goals and procedural mechanisms combine to give structure to governance activities [5]. As such, global health governance is closely linked with global health law (GHL), which can be defined as a system of legal [6] norms concerning the promotion of health and organisation of healthcare for the global population ${ }^{1}$. Law is viewed in functional terms as a system stabilising normative counterfactual expectations over time, rather than a set of norms adherent to a particular form of international law. It is the autonomous emergence and constitutional formation of the legal system regulating global health-largely overlooked in analytical discussions - that is the subject of the following analysis.

There are three main reasons why a discussion about a global health constitution is crucial at this point. First, global health faces a number of difficult practical challenges, including: (a) the vast expansion of health concerns, ranging from HIV/AIDS, malaria, and Severe Acute Respiratory Syndrome (SARS) to non-communicable diseases, obesity and mental health issues [7-11]; (b) globalisation of ecological and sanitary risks through technological advances; (c) the actual and predicted substantial climate change exacerbation of health hazards in the coming decades; (d) the structural changes in global health governance and funding ${ }^{2}$; and finally (e) the digitisation and globalisation of medical research and health care services. This rise in interest and funding in global health facilitated admirable achievements, such as meeting the Millennium Development Goal (MDG) target on drinking water ahead of schedule, the end of polio transmission in India, or the dramatic reduction of the number of people contracting HIV/AIDS every year. However, this unprecedented engagement has still left most problems unsolved and today the provision of, and access to, health care ${ }^{3}$ in low- and middle-income countries continue to cause 20 million deaths annually, mostly among the world's poor [14]. Eradicating

1 Whether GHG is to be seen as including or just overlapping with GHL is a matter of some debate. The author takes the view that the two systems are overlapping. An example of legal norms which — as will be argued here-would be part of GHL, but not necessarily be associated with GHG are norms created by decisions of national constitutional or supreme courts concerning health, or administrative/procedural norms allowing for such litigation to occur.

2 Global governance for health is understood as "the collection of rules, norms, institutions, and processes that shape the health of the world's population". See: [12].

3 The distinction between "health care systems" and "global health" adopted in this paper follows the differentiation made by Daniels between the right to health care and the right to health. According to Daniels "the right to health care" includes both the right medical services and public health measures, whereas "the right to health" is defined more broadly as a way to characterise functionally the relevant, socially controllable actions that affect population health and its distribution. See: [13]. Due to the fact that the field of global health clearly exceeds health care services which are predominantly delivered at the national level, this papers refers to health care systems at the national level and global health system at the international/global level. 
poverty and persisting health inequalities remains one of the most important goals in the recently adopted post-2015 Sustainable Development Agenda ${ }^{4}$. Second, at present, global health law and governance are seen as institutionally, normatively and thematically fragmented. This fragmentation has been closely linked to the increasing dominance of non-state actors in international health policy, accompanied by a simultaneous dramatic decline of the World Health Organisation (WHO) leadership [15,16]. It has been illustrated for instance in the increasingly complex interplay between horizontal and vertical health systems [17]. The institutional and normative plurality is often seen as hindrance to the creation and sustainment of effective and coherent responses to the above-mentioned global health challenges ([11], p. 1). Despite the WHO reforms, almost all depictions of global health bear a sense of failure and continuous crisis ${ }^{5}$ This constitutes a substantial obstacle if global health system is to be capable of negotiating its position, and becoming reliable partner for political co-ordination efforts in a global - if thoroughly fragmented - constitutional order.

Last but not least, despite its increased prominence on the international agenda and many academic debates among public health experts, lawyers and sociologists, there have been few attempts to develop a comprehensive conceptualisation of the developments in the field of global health law [9]. Most public international and global/transnational law $[20-24]^{6}$ scholars address quite general problems of global/transnational constitutionalism and fragmentation, and in most cases they engage with issues of global health and global health law only peripherally, usually as one aspect of wider accounts of WTO, IP law, human rights, or environmental protection [25-27]. This is intensified by the fact that public and private forms of transnationality are considered in two separate discourses [28]. A similar schism can also be observed in discussions about global health law, which is often seen either as tantamount to public health law ${ }^{7}$, or global health governance ([2], pp. 3-41). Public health lawyers usually focus on

4 UN General Assembly Resolution A/70/L.1, Transforming our world: the 2030 Agenda for Sustainable Development, 25 September 2015, A/RES/70/1.

5 Global Health and Foreign Policy, United Nations res. 63/33, United Nations A/RES/64/108 (27 January 2009). The future of financing for WHO: World Health Organization: reforms for a health future: World Health Assembly A64/INF.DOC./5 (12 May 2011); See also: [18,19].

6 For the purposes of this paper, the terms global and transnational will be used interchangeably for the following reasons. On the one had, global law has been defined by Teubner as a new body of law that emerges from various globalization processes in multiple sectors of civil society independently of the laws of the nation states. See: [20]. As such it is focused on non-state, private systems of governance. Furthermore, according to Kingsbury the term "global" (in Global Administrative Law) includes informal institutional arrangements and other normative practices and sources that are not encompassed within standard conceptions of "international law", but can be conceptually derived from national administrative (i.e., public) law principles (see: [21]). At the same time, the term "transnational law" was defined by Jessup as "all law, which regulates actions or events that transcend national frontiers. Both public and private international law are included, as are other rules, which do not wholly fit into such standard categories". See: [22]. Today, transnational law is often seen 'as a myriad web and "assemblage" of intertwining, both public and private, that is hybrid, forms of regulation that can no longer be easily associated with one particular country or, for that matter, one officially mandated rule making authority'. Those who subscribe to this view treat transnational law as conceptually distinct from national and international law because its primary sources and addressees are neither nation state agencies nor international institutions founded on treaties or conventions, but private actors involved in transnational relations. In this latter sense transnational law clearly overlaps and can be seen as tantamount to global law. See: [23]. See also [24].

7 See [29]. The distinction between public health law and medical law will be examined at a later point in this paper. 
particular regulatory problems (HIV/AIDS, pandemics, tobacco control, non-communicable diseases), while global health governance scholars are preoccupied with the institutional and organisational layout. Despite close links between global health law and governance, theorisations of both fields remain remarkably separate. Human rights lawyers and moral philosophers interested in issues of individual and global justice usually occupy the analytical space between these discourses. At the same time, legal, ethical, and sociological studies of biomedicine ${ }^{8}$ tend to focus, also in relative isolation from each other, on very particular themes, such as medical research, genetics and genomics, or assisted reproduction. In short, despite the proliferation of legal norms, thus far there is little research that examines how health care norms are shaped and implemented, and what the wider unifying normative features of global health might be. This constitutes a theoretical gap in a number of fields of research, and it has relevance, not only for public health experts, but also for constitutionalists and transnational lawyers, and legal theorists.

This paper aims to address this gap. It attempts to answer three urgent questions: (1) Is coherent theorisation of a global health law system possible? (2) Can we observe the process of constitutionalisation ${ }^{9}$ of the global health regime? (3) And, if so, what are its features and patterns of development? In addressing these questions the paper's underlying explanatory aim is to examine the legal dimension of global health system, i.e., whether recent forms of juridification of global health, reflected for instance in the consolidation of health rights jurisprudence, amount to constitutionalisation of global health. The paper constructively utilises insight derived from theories of legal fragmentation, global legal pluralism, and transnational and/or global constitutionalism, which acknowledge "the incommensurability of authority claims - in particular of the discrete claims to final authority over the interpretation and extent of jurisdiction of the various political units" 10 and share the vision of "the disorder of orders - countless analytical and normative proposals competing for influence" [32]. Within this framework, Gunther Teubner's concept of self-constitutionalisation of "social fragments" [33] provides a useful starting point and language for discussion [34]. Teubner acknowledges that at the domestic/state level societal orders constitute themselves in parallel with politics and develop their identity and formal rationality through a slow and complex process of specialisation. At the global level, however, societal constitutionalism actually involves non-political constitutionalisation of global governance in which "private actors not only participate in the political power processes of global governance, but also establish their own regimes outside of institutionalized politics" ([33], p. 9). In Teubner's view, constitutionalism has the potential to "effectively limit [the] destructive effects" ([33], p. 1) of expanding subsystems in global society and to react to crises or threats to individual or institutional autonomy created by sectors such as global economy, education, science, technology, and medicine. Thus, constitutionalism is linked with both the private sphere and the transnational realm. In this respect, global health law constitutes a fascinating, yet challenging subject of analysis, because its

8 The term "biomedicine" here is neutral and carries no pejorative connotation to a specific model of health care. Rather, it describes the branch of medicine that uses and develops new technologies in medicine, and stands at the intersection of health and science.

9 The concept of "constitutionalisation" describes the emergence of constitutional law within a given legal order. It implies that a constitution or constitutional law can come into being in a process extended through time. It may be, in short, a constitution-in-the-making.

10 See [30]. For an overview of pluralist theories: [31]. 
recent unprecedented expansion encompasses not only the private, but also the public sphere. The relevance the public sphere (public law and politics) for the constitutionalisation of global health casts some doubt over Teubner's vision of private orderings.

Nevertheless, first and foremost, the approach taken in this paper offers unique analytical lens for examining the dynamic processes of system formation within particular functional regimes emerging at the global level. Moreover, it helps construct coherent conceptualisation of the prima facie chaotic expansion of legal, ethical and professional norms created by public, private, and semi-private actors in the field of global health. As a result, these developments can be viewed, not necessarily as yet another crisis or a systemic failure, but rather, as a new stage in the growing constitutional autonomy and organization of global health law. For the purposes of this paper, a constitution is viewed to provide "a basis for stabilisation of the systems in question through legal means, as well as for the establishment of reflexive mechanisms capable of ensuring that they exercise self-restraint to a degree which leads to a reduction in negative externalities, asymmetries and crowding-out effects vis-à-vis other systems" ([28], p. 314). This understanding necessarily departs from the traditional definition, which perceives a constitution as "the sum of basic legal norms which comprehensively regulate the social and political life of a polity" [35]. However, the adopted conception helps to address the "open source anarchy" of global governance [5] and capture the complex developments occurring in the realm of transnational law. Additionally, although admittedly formalistic, it does not preclude the existence of values and principles underlying the processes of constitutionalisation of global health. At the same time, despite the undeniable relevance of values such as global health justice and equity, the focus of this paper is not the content of the constitutional principles, but the processes contributing to the emergence of a new field of transnational law.

The first section of the paper sets the development of global health law against a political and regulatory background highlighting the inner fragmentation of global health regime. In this context it briefly considers the "constitutional" aspects of regime formation. Subsequently, the paper assesses global health in light of essential criteria of sectorial constitutions. It is argued here, perhaps controversially, that, although the constitutional construction of global health is far from complete, it is possible to observe an increasing level of constitutional order in some areas of global health law, such as HIV/AIDS or biomedical law. At the same time, as the analysis proceeds and recent developments in the global health system are considered, points of contention, where global health law escapes straightforward categorisation and classification in terms of constitutional theory are identified, and the questions for future research are outlined. Establishing all of these issues is far from straightforward. The following analysis does not offer (or indeed advocate) unity, uniformity, or even harmonisation of global health law, but it is an attempt to "compose a mosaic, which is not done by throwing various pieces haphazardly, but by combining them such that they create as harmonious a design as possible" [36]. A normative vision of global health law provides a necessary template for that mosaic.

\section{Conceptual Quandaries over the Global Health Law System}

\subsection{Institutional and Normative Fragmentation of the Global Health System}

Since the adoption of the WHO Constitution in 1948, global health has been usually associated with the World Health Organisation as the undisputed leader in the field. As stated in its Constitution the 
WHO is destined to "act as the directing and co-ordinating authority on international health work"11. It is often claimed that it should act as an umbrella health agency convening legal and non-legal activities of different organisations providing thereby a more effective collective management $[15,16]$. The Constitution was intended to set out formal foundations for the operation of the WHO and guarantee coherency of the global health system. However, the internal consistency turned out to be illusory, and it soon transpired that other actors, such as UNICEF, would also claim authority and expertise over health issues, such as immunisation programmes or maternal health (the regulation of breast milk formula) [37]. The position of the WHO was later further undermined by globalisation and the emergence of new stakeholders, including governmental and non-governmental organisations, philanthropic foundations, professional networks, religious groups, private-public partnerships, and private companies. Instead of reforming and strengthening existing organisations with explicit health mandates, greater energy has gone into creating new actors and expanding the mandates of others [38]. One of the causes of this proliferation can be traced back to market-driven global economic policies associated with structural adjustment programmes (SAPs) and extended intellectual property rights implemented by the World Bank and the International Monetary Fund. As part of the push toward increased commercialization in health care systems and trade openness, SAPs sought to redirect foreign aid to NGOs and away from governments. The World Bank, US Agency for International Development (USAID) and other major donors began channelling large proportions of their health funding to private actors, thus, strengthening the delivery of health care through vertical health systems. It is often argued that this reconceptualization of health politics and funding has undermined the grand vision of comprehensive primary health care promoted by the WHO [39], some of the traditional structures designed to address cross-border health concerns ([11], p. 1) and health reforms in low-income countries [40]. At the same time, the health sector has resisted attempts to measure its efficiency and effectiveness, avoiding close monitoring and accountability. This situation has led to fierce criticism by global health experts including Gostin, who aptly observes that "[t]here is deep fragmentation of global health actors, such that there is vast duplication of effort (think of endless reports that health ministries must compile for different partners). Global health institutions have failed to articulate clear objectives and take steps to accomplish desired common goals. Priorities are badly skewed, such that funding and programs are disproportionately targeted to politically popular programs and the latest high profile disease (think of SARS, influenza, and bioterrorism) rather than the global burden of disease (think of cancer, heart disease, mental health, and injuries). Health often is given inadequate weight in other regimes, such as trade and investment, despite their impact on health" ${ }^{12}$. However, not for everyone the situation is as grim as for Gostin. For instance, Fidler views recent changes as a shift from state-centric "old-school anarchy" to pluralistic and unstructured "open source anarchy"; from a Westphalian to a post-Westphalian context, in which both States and non-State actors shape responses to transnational health threats and opportunities. Moreover, interestingly, Fidler notes a deep paradoxical causal link between the absence of architecture for global health and the growing importance of health in

11 Art. 2 (a) of the Constitution of the World Health Organization as adopted by the International Health Conference, New York (19-22 June 1946) (Official Records of the World Health Organization, no. 2, p. 100), entered into force on 7 April 1948.

12 See ([3], p. 30) and see the system as frequently ineffective, increasingly chaotic, and highly dysfunctional. 
global politics over the last 20 years. According to Fidler, "open-source anarchy allows all manner of actors to access, adopt, apply, and adapt to the source code for global health, creating a governance effect far more vigorous than WHO ever managed to create as an intergovernmental organization" ([5], p. 10]). At the same time, however, Fidler acknowledges that open-source anarchy creates enormous difficulties for the task of building and maintaining adequate public health infrastructures locally, nationally, and internationally. Despite the globalization of public health, the political and financial responsibility for public health infrastructure and capacity falls on governments. Alas, open-source anarchy constitutes a serious obstacle in building sustainable capacity for public health within and between states ([5], p. 13). This is where questions about law become crucial.

The law created in this heterogeneous environment has been said to be developing in an uncoordinated, amorphous, and incomplete manner, forming a system, which is ineffective and highly dysfunctional [2]. States (and non-state actors) frequently fail to comply with stipulated legal rules and change their behaviour as a result of a treaty or a declaration ([9], p. 438) What exacerbates the practical and conceptual difficulties is the extraordinary proliferation of soft-law instruments and other forms of regulation, accompanied by perhaps comparatively modest number of traditional international law provisions and latent processes of juridification ${ }^{13}$. Despite WHO's astounding normative powers, modern international health law is remarkably thin. There currently exist three legally binding international health instruments (International Classification of Disease 1948, International Health Regulations (IHRs) [41], and WHO Framework Convention on Tobacco Control 2003 (FCTC) [42]), and two of them predate WHO. These instruments are often characterised by "structural weaknesses - e.g., vague standards, ineffective monitoring and weak enforcement - and a 'statist' approach that insufficiently harnesses the creativity and resources of non-state actors and civil society" ([2], p. 240). Their impact is severely weakened by the fact that they provide no financial or technical support to do so, member states may reject or submit reservations to their provisions, and most importantly they lack enforcement mechanisms for addressing compliance failure ([9], p. 435). For instance, one analysis of the IHRs effectiveness over their 56-year history concluded that, due to poor national surveillance systems and protection measures, they had been relatively ineffective in achieving their main goals [43]. On the other hand, the FCTC remains the first and only legally binding global health treaty. It was criticised with regard to its formation and content [44]. Together with other WHO instruments it still neglects rights-based terminology [45] and it covers an extremely limited subject matter, which prevents it from being a centre of an emerging global health regime. Consequently, some argue that despite numerous legislative attempts, like the joint WHO/UNICEF Alma-Ata Declaration 1978 [46], the WHO has been reluctant to pursue international law and human rights approaches to public health issues ${ }^{14}$. This standpoint can be supported by the fact that it was the UN Assembly and UNESCO, and not the WHO, that adopted the three famous international human rights instruments in the area of biomedicine and bioethics, discussed below $[47,48]$. Similarly, it is now the UN Committee on Economic, Social and Cultural Rights (CESCR), which has recently assumed quasi-adjudicative functions over the right to

13 "Juridification" is a term used by Teubner (2012) and it seems to be tantamount to "legalisation" used by Klabbers (2009) and Krisch (2010) to describe proliferation of treaties and the creation of ever more courts and tribunals. Despite subtle differences they will both be used interchangeably.

14 See [43]. It is worth mentioning that it was UNESCO and not WHO, who adopted the three human rights instruments in the area of genetics and bioethics. 
health at the international level ${ }^{1516}$. Finally, field of global health remains predominantly "soft", in that it is dominated by declarations, communications, recommendations, resolutions, codes of practice, guidelines, notices, and positions ${ }^{17}$. However, it is also becoming increasingly entangled with various sources of obligation - including national law (assisted reproduction laws), other international law regimes (WTO, environmental law, ILO, World Bank), regulations of international organisations (WHO, UNAIDS, UNESCO), contracts between private parties or informal rules and institutional arrangements. This institutional and normative fragmentation obscures the determination of the normative character of global health law [4,51]. This is most probably one of the reasons why, although global health should be a major focus of international law, sadly that has not been the case. Of course, this is not to say that debates about global health never enter the international arena. On the contrary, attempts to conceptualise recent developments and design possible solutions to global health challenges have been mounting. These responses can be divided into normative and analytical.

\subsection{Responses to Fragmentation of the Global Health System}

As far as normative responses are concerned, prominent voices have called for more unity through harmonisation, co-ordination, and synchronisation of the area. These calls highlighted the need to create "the scaffolding to sustain healthy, ecologically sound, and equitable global systems" and a more "holistic approach to the global architecture of health aid" [52] have been made to "constitute the scaffolding to sustain healthy, ecologically sound, and equitable global systems" [53]. For many years global health scholars and practitioners have been advocating the idea of codification via a legally binding global health treaty. In April 2011 it seemed that their call shave been finally heard, when the United Nations General Secretary, Ban Ki Moon, asked political leaders "to commit to global solidarity, built on the tenets of shared responsibility, true national ownership and mutual accountability...and set the stage for a future United Nations Framework Convention on Global Health" [54]. A framework convention would use a bottom-up inclusive process to inter alia: (1) set globally-applicable norms and priorities for health systems and essential human needs; (2) effectively govern the proliferating number of actors and activities; (3) create methods for holding state and non-state actors accountable to the right to health obligations, including for monitoring progress and achieving compliance with the Framework Convention on Global Health (FCGH) itself; and (4) devise a process for the international community to establish further commitments beyond those in the initial Convention ([12], pp. 74-75). However, almost five years later, the FCGH still remains in a remote plan and it is to be seen whether, and if so when, it will become a legal reality. Doubts over feasibility and appropriateness of such proposals are reinforced by Fidler's metaphor of the open source anarchy, in which health's role in global affairs can no longer be captured politically or analytically through a single governance structure or distinct architectural framework. Furthermore, according to Fidler "the process of bringing order to

15 Optional Protocol to the International Covenant of Social, Economic, and Cultural Rights 1966, UN General Assembly Resolution 63/117, 10 December 2008.

16 It was also the Committee on Economic, Social and Cultural Rights that issued the General Comment No. 14: [49].

17 This proliferation is well illustrated, for instance, on the WHO website enumerating guidelines and codes of practices issued by the organization on different subjects. The most famous one issued recently is the WHO Global Code of Practice on the International Recruitment of Health Personnel, at [50]. 
unstructured plurality confronts the resistance of both States and non-State actors to have their prerogatives and freedom of action restrained. We are familiar with such resistance from States under old-school anarchy, but those interested in global health governance should not underestimate the wariness with which non-State actors would view attempts to rationalize, centralize, and harmonize their involvement in global health" ([5], p. 8). Fidler conceptualisation of global health governance is analytically closely linked to theories of global fragmentation, legal pluralism, and global/transnational constitutionalism. However, because he seems to view law as one of many tools used in global governance, the relevance of legal norms in the development of the global health system remains largely unexplored. As will become clear from the following analysis, theories of global fragmentation and transnational constitutionalism have the potential to refocus debates in the field of global health and address the questions posed at the beginning of this paper.

\subsection{Global Health through the Lens of Global Pluralism and Transnational Constitutionalism}

There have been numerous attempts to theorise fragmentation and pluralisation of law and "the Great Legal Complexity of the World" [55]. The International Law Commission (ILC) Study Group, which adopted a more traditional understanding of international law, analysed the emergence of so called "self-contained" systems [56], established around functionally specialized international organizations. In a broad sense such "special regimes" ([57], para. 365) constitute a group of primary rules and principles concerned with a particular subject matter that is applicable as lex specialis, i.e., that is able to seek precedence in regard to the secondary rules provided by general international law. ILC identified different possible criteria for identifying such regimes ${ }^{18}$, including, the presence of a special set of (secondary) rules concerning breach of a particular group of (primary) rules [59], rules for the creation, interpretation, application, modification, or termination of rights and obligations, covering a special subject matter set out in a single treaty, several treaties, or treaty plus non-treaty developments (such as subsequent practice or customary law), and effectiveness [60]. Prima facie, global health law seems a perfect candidate to be classified as a self-contained regime. After all, the institutionalisation of global health has been taking place gradually for a long time. First general rules and standards developed to govern sanitation and trade-related health concerns as well as rapid scientific discoveries during the 19th century. This period was dominated by the development of domestic state public health interventions [61]. The second wave marks the consolidation of norms and standards at the end of World War II with the creation of the WHO and assisted UN specialized agencies working on health provisions, as well as the occurrence of NGOs dealing with health as a part of development and reconstruction. This seems to have been the time when the formation of a self-contained regime was most likely to happen. Finally, further institutionalisation took place in the early 2000s with the rise of private-public partnerships ([51], p. 27). It is legitimate to ask whether this institutionalisation lead also to juridification of the area and the formation of a self-contained regime. The earlier account of global health law might cast great doubt on this issue. First, as mentioned above, the leadership role of the WHO has been contested over the years. Secondly, it is impossible to identify a specific treaty

18 The ILC preferred the term 'special regime' over 'self-contained regime', since no evidence is found supporting a full exclusion from general international law. However, as the latter notion has been adopted in case law and scholarship it will be used here. For detailed definition see: [58]. 
outlining rights and obligations as well as secondary rules that would form a lex specialis to general international law principles ${ }^{19}$. Global health law remains fragmented and lacks a common legal point of reference to appeal to for resolving its internal or external conflicts. Third, there is no separate adjudicative body that would seek to interpret existing rules concerning global health and provide some kind of dispute resolution. The WHO has never used the dispute procedure outlined in its Constitution, and it remains to be seen whether the UN CESCR successfully exercises its new powers set out by the 2008 Optional Protocol to the ICESCR. Finally, with regard to the third understanding of the self-contained regime, the identification of particular "branches of international law" has become increasingly difficult. The shift towards multisectorialism and the involvement of global financial institutions and private bodies in global health governance make such delineation extremely challenging. Therefore, from a classical public international point of view, the system of global health law, despite displaying some features of a self-contained regime, would most probably escape such a categorisation.

Today the debate in international law has moved forward, away from self-contained regimes ([58], para. 152). They are now understood as interrelated sub-systems in the field of international law with relationships to both general international law and other sub-systems in the international law. Theories of global pluralism and transnational constitutionalism analyse a legal system, that is not simply the inter-state system, where a convincing rule of recognition has not been formulated, the institutions for "adjudication" are often non-judicial and sometimes absent, and the processes of change are not easily articulated in terms of rules [62]. In general, the discourse revolves predominantly around the concept of legitimacy, effectiveness, fundamental values, and different foci of authority. However, the criteria of legal validity and regime formation proposed by these theories vary substantively from more formalistic models to very pluralised and flexible. For instance, for Neil Walker levels of constitutional consolidation will depend on: (a) the adoption of a self-conscious constitutional discourse; (b) the assertion of sovereignty; (c) the development of jurisdictional scope; (d) a claim to interpretive autonomy; (e) the exercise of a residual institutional capacity; (f) the specification of the incidents of citizenship of the polity; (g) and the construction of mechanisms, such as representation, for realizing that citizenship [63]. In contrast, according to Krisch, pluralist models have a broader appeal than constitutionalism in the construction of postnational authority and law as they reflect the need for multiplicity and stress the value of fluidity and openness. "Pluralism occupies a middle ground between hard, legalized and softer network forms of cooperation and thus combines greater flexibility with those of (limited) hierarchical instruments" [64]. In the pluralist world conflicts are solved through convergence, mutual accommodation or not at all. Kingsbury, on the other hand, focuses on normative coordination and institutionalization concerned with the administration of general public goods (i.e., with "global administrative law") and proposes a substantive validity paradigm based on the notion of "publicness" reminiscent of Fuller's concept of law. The notion of "publicness" is helpful for the analysis of global health law to the extent to which the latter regulates the administration of health care. In becomes clear that in this respect some aspects of global health law could be characterised as global administrative law. Nevertheless, this approach has also certain important limitations. It precludes the analysis of these aspects of global health

19 That conceptual frame constituting a starting point for the ILC's Report was provided by the Vienna Convention on the Law of Treaties of 1969 (VCLT) (23 May 1969), entered into force on 27 January 1980, United Nations, Treaty Series, 1155: 331 . 
law, which falls outside administrative law, including contracts and other forms of obligations, which proliferate in the context of cross-border flow of patients, doctors, and funds, and which play an important role in the development of global health law. Consequently, it is not conducive to an in-depth systematic study focused exclusively on global health law. What is appealing in Teubner's vision is that it is operational: regimes are not founded by anyone or anything, and they are a sum of communicative operations of different actors. A constitution is seen first and foremost as a living communicative process. Its main objective and role is not so much to impose unity upon the regime (which as we have already established is unattainable), but to construct its identity with the assistance of law. It is in this respect, that Teubner's concept of societal constitutionalism becomes a useful point of reference and providing language for further analysis.

Societal constitutionalism based on the idea of self-constitutionalisation of functional systems is the response to the monetarisation, scientification, and medicalisation of society ([35], p. 24). At the national level, constitution law is necessary to stabilise the spontaneously reproducing and conflicting systems. When functional regimes (economy, science, medicine) become global, pressure exerted by the state to set limits and navigate their outward expansive tendencies and regulate the conflicts between regimes disappears. The lack of political or legal framework facilitating internal and external communication, can lead to an unprecedented expansion of the system. For example, absence of clear legal rules concerning extraterritorial liability of states and private actors can have serious negative effects on the health of patients who receive healthcare abroad and healthcare professionals, who provide it. Another example would be the continuous failure to deal effectively with epidemics, including HIV/AIDS, allegedly stemming from the discrepancy between the expansion of global health actors like UNAIDS, Global Fund, BMGF on the one hand, and very limited legal commitments on the other. Of course, alternatively, it could be argued that Teubner's interpretation of the developments at the global/ transnational realm fails in the context of global health, because in the field of global health "constitutional moments" occur not as a result of regime expansion, but as consequence of external factors. Some could say that human health is by definition fragile and pandemics like Ebola or H1N1 (swine flu) are simply inevitable periodic occurrences. Other would argue (more convincingly) that many, if not most, illness could be prevented or cured, if health care systems were not constantly undermined by the excessive growth of the free market economy. Accepting this reasoning thus undermines the basic premises of societal constitutionalism, which traces the need for self-constitutionalisation back to the system itself. It would also seem to question the response to crisis. While self-constitutionalisation is said to aim at limiting the expansionist tendencies of a system, in the area of global health the response to a crisis is always more health care, not less. Law is usually created to extend health systems and strengthen the delivery of health services. It is difficult to disagree with such analysis. However, certain reservations have to be made, because the realities of global health are even more complex and may nevertheless lend some weight to the argument that the expansion of the global health system may lead to a constitutional moment. An example would be the establishment and development of vertical and horizontal health systems. Vertical programmes created to tackle specific health problems, funded and operated by IOs, NGOs and private actors, have dominated health systems in some developing countries, leading to their deterioration and collapse of horizontal systems, which usually lack funding and support [65]. Calls for legal regulation of this area do highlight the need for structural changes in the delivery of healthcare rather than the expansion of 
anyone of these types of systems. According to Teubner, it is at that moment that the pressure for global self-foundation (and autonomisation) increases and reveals its "jurisgenerative potential", and it is then that subsystems of world society are beginning to develop their own constitutional legal norms ([66], p. 59). Full sectorial self-constitutionalisation is impossible without legal norms enabling and supporting the accomplishment of system's full autonomy ([35], p. 107). However, Teubner distinguishes juridification from constitutionalisation of a functional regime and sets certain criteria against which the latter should be assessed. First of all, norms need to perform two main constitutional functions, namely provide for the self-foundation and self-limitation of the subsystem. Second, they have to maintain the internal differentiation of the system, which will accommodate certain constitutional arenas, i.e., the organised-professional sphere, the spontaneous sphere, and learning processes between them. Third, they have to sustain double reflexivity of the system, and through the development of constitutional processes (i.e., secondary norms), support the accomplishment of system's autonomy. Last, but not least, they need to form constitutional structures, which will stabilise the constitutional function and processes in the constitutional arenas and enable the distinction between constitutional and non-constitutional norms. The following analysis of the global health regime demonstrates the existence of most of those elements, allowing us some optimism with regard to the formation of a global health constitution in the future.

\section{The Constitutional Development of Global Health Law}

\subsection{Constitutional Moments in the Development of Global Health Law}

\subsubsection{The Post-War Constitutional Foundations of International Health}

It can be argued that global health law like other global regimes does not strive towards a stable balance, but rather follows the chaotic pattern of a "dynamic disequilibrium" between contradictory developments: the autonomisation and the limitation of its functional logic ([33], p. 76). Freed from the framework and territorial boundaries of the nation state global health system exhibits tendency of expansion. As a result of scientific advancement new illnesses are being identified, new conditions medicalised, and new public health areas brought at the forefront of policy-making. This creates a pressing need for "cure", i.e., more health care, more pharmaceutical products, treatments, and more medical research, which in turn generates new categories of disease. Similarly, in science, research generates uncertainties, which can only be solved by more research, in turn producing even more uncertainties. However, at the global level there are no state structures to balance, limit, and bring stability to these developments. Consequently, both regimes - medicine and science - are undergoing processes of self-reproduction and maximization of their particular rationalities, which become excessive. This specific growth compulsion can lead to a catastrophe. The experience of immediate crisis brings to the crucial realisation that self-restraint is vital. The need to formulate limitative rules becomes vital in order to counteract self-destructive tendencies and to limit the damage to social, human, and natural environment ([33], p. 76). This is when the "constitutional moment" ([35], p. 81) occurs. Teubner states that "this is not yet the moment when the self-destructive dynamics makes the abstract danger of collapse appear (...), it must be one minute before midnight" ([35], p. 82). It seems that in the development of global health law, there was not one, but a few such constitutional moments. The first 
constitutional moment can be traced back to the Second World War, and some will argue that it came not before, but just "after midnight", namely after the atrocities committed by doctors in the name of science or greater public good. The second one is associated with the global response to the HIV/AIDS pandemic that led to the emergence of a new global health paradigm. Finally, the third, and most recent, constitutional moment has occurred in the context of the biotechnological revolution. This might come as a surprise, especially to those who associate constitutionalisation with some form of codification through treaty law, because apart from one binding regional document, i.e., the Convention on Human Rights and Biomedicine 1997, the area is populated by non-binding instruments or no international law at all.

As a result of the catastrophe of the Second World War, some of the most important norms of the global health system have been adopted in the Nurnberg Code (1947) [67] and the WMA Helsinki Declaration on the Ethical Principles for Medical Research Involving Human Subjects (1964) [68]. They both established the principle of physical and mental inviolability and the ban of medical experimentation without consent. These rules have been then translated into Art. 7 of the International Covenant on Civil and Political Rights (1966), and subsequently developed by the Council for International Organizations of Medical Sciences (CIOMS) in the International Ethical Guidelines for Biomedical Research involving human subjects (2002) [69]. Art. 7 is an important part of the ICCPR and has been designated as one of the provisions that is non-derogable and allows no limitation. The UN Human Rights Committee has made it clear that "no justification or extenuating circumstances may be invoked to excuse a violation of Article 7 for any reasons" ${ }^{20}$. The above norms seem to simultaneously fulfil the two constitutional functions, namely they support the self-foundation and self-constraint of the system. In a sense then, the somewhat linear development of constitutional law stipulated by Teubner (i.e., first self-foundation of the system, and then its self-limitation) does not apply to the area of medicine and science. It could be said that the self-foundation of the health regime at the global arena as an autonomous system has been partly induced by the need for its self-limitation.

Another manifestation of the post-war constitutionalisation was the adoption of the set of norms relating to the right to health. First of all, the establishment of the WHO was described as "an extraordinary advance in the evolution of international health institutions" and "the broadest and most liberal concept of international responsibility for health ever officially promulgated" [71]. In a most self-constituting fashion the WHO labelled its founding document (the WHO Constitution) a "Magna Carta of Health" [72]. The inclusion of a new "right to highest attainable standard of health" defined as "a state of complete physical, mental and social well-being and not merely the absence of disease or infirmity" was surely directed at the creation of the internal rationale and identity of the global health care order. In the first 30 years of its existence the WHO has focused on a combination of vertical and horizontal health strategies culminating with the adoption of the Alma Ata Declaration in 1978 and the eradication of smallpox in 1980 [73]. The aim of the former was to reaffirm the right to health, but predominantly to consolidate the member state support for global health and reassert the central role of the WHO in the global health governance. The latter was seen as a triumph for the WHO in terms of its ability to effectively coordinate research alongside state interests and public-private investment.

20 See [70]. The issue of enforceability of Art. 7 arises in this respect, but it constitutes a problem of the whole human rights regime. 
However, the recent proliferation of organisations getting involved in global health governance sets a trend that undermines initial successes. In fact, so many actors and organisations are involved that coordinating the bewildering array of initiatives and programmes becomes impossible [74].

Although the role of the WHO has diminished considerably over the years, and the definition of health has been severely criticised as vague and ambivalent, it contributed to the development and subsequent expansion of the regime and the inclusion of issues and dimensions such as poverty, inequality, gender, and stigma in the health agenda [66]. The right to health, rooted in Art. 12 ICESCR and greatly extended through the General Comment No. 14 (2000) to include health determinants, has provided a broad and flexible framework to deal with a number of health issues, ranging from access to treatment to bioterrorism. $[75,76]$. The right to health constitutes probably one of the most controversial human rights developed in the post-war order, yet it has been reproduced in different "shapes and forms" in numerous documents, some of which certainly carry a constitutional status [77]. The Universal Declaration of Human Rights 1948 called for a standard of living adequate to health and well-being in Art. 25(1), Art. 12 of the ICCPR 1966 enumerated the detailed state obligations in this regard, and more recently the Oviedo Convention 1997 promulgated "the equitable access to health care of appropriate quality" in Art. 3. The right to health has been often proclaimed to be a well-established part of international law ([77], p. 133). The four elements underpinning the right to health, i.e., availability, accessibility, acceptability and quality have constituted the basis for most global health actions. It also defined the global health regime's rationale during disputes with WTO/TRIPS Agreements or the World Bank, which represented great examples of regime collisions. The attempts to define the communicative and normative boundaries of the global health regime through the right to health might not always have been successful, but despite endless criticism the right can still be seen as defining the regime's distinct identity and supporting its autonomy. The association between health and the language of human rights has been exceptionally successful over the last years and is slowly pervading all areas, levels, and forms of global health [78,79]. It also supported the unprecedented expansion of health rights that coincided with their intensive judicialisation and constitutionalisation across the world [80,81]. The relevance of the right to health as the central notion of global health has been further considerably strengthened during the second period of constitutionalisation, instigated by the AIDS/HIV crisis.

\subsubsection{The HIV/AIDS Crisis and the Emergence of the Global Health Paradigm}

The outbreak of the AIDS/HIV pandemics constitutes another vital point in the constitutional development of the global health system. The experience of a major crisis and state of emergency that accompanied the outbreak of the pandemics and its subsequent development has been followed by an emergence of multiple non-state actors and an increased regulatory activity. Initiatives, such as the Joint United Nations Programme on HIV/AIDS (UNAIDS), launched in 1994, the Global Fund to fight AIDS, tuberculosis, and malaria, created in 2002, or the - to name only a few - have led to well-funded projects and fundamental changes in funding structure [82]. More recently, in June 2010 a new body, the Global Commission on HIV and the Law ("comprising eminent persons from public life"), was launched to develop human rights-based recommendations for effective HIV responses, complementing the UNAIDS High-Level Commission on HIV Prevention and supporting the achievement of the 
Millennium Development Goals (MDGs) [83]. This proliferation of global actors required a considerable amount of regulatory activity at the global level. All actors involved in the HIV/AIDS agenda (e.g., WHO, UN, UNAIDS, Global Fund, UNFPA, World Bank, etc.) started issuing political declarations (on HIV/AIDS 2001, 2006, 2011) [84], numerous policy reports, and various guidelines, including the WHO consolidated guidelines on the use of antiretroviral drugs for treating and preventing HIV infection [85]. Furthermore, far more effective standard-setting tools, such as procurement and supply management requirements [86] and quality assurance tools [87] have been used to award development grants and distribution of health services and products. Although no binding international treaties have been adopted, many would argue, the institutional and normative proliferation that has taken place within and outside the aegis of the UN and WHO was a key driving force behind the fundamental changes in the post-MDG global health landscape.

These developments have certainly supported the self-foundation of a global health law regime and some would claim that it was in that moment that the new global health paradigm has emerged ([82], p. 137) Although the HIV/AIDS exceptionalism [88] followed by vast investment directed at tackling HIV/AIDS epidemics that ignored other important health issues (e.g., non-communicable conditions) have been heavily criticized [89], the proliferation of various actors and a new body of soft law regulation certainly marked a shift of constitutional importance in the field of global health. The mobilisation of the international community including especially high-income countries highlighted the link between the global health agenda and issues of global justice, which has since become one of the central motifs of the global health system. The sense of global health crisis has triggered acute realisation of common responsibility for advancing the global health agenda. Subsequently, through the problems with availability of anti-retroviral therapy (ARTs) in developing countries, it instigated debates about access to generic medicines, which resulted in the disputes between WHO and WTO. These disputes, although revealed great imbalances of power between the two regimes, have also helped refining the fundamental principles and objectives of the global health system. They have paved the way to the strengthening of the rights-based approach to health, especially the enforceability to the right to health. This development has been far from straightforward. Over the years, individual claims concerning access to medicines and health services have been brought either against individual states, or against multinational pharmaceutical companies [89]. Domestic courts in both developed and developing countries have used rights transposed into national constitutions from international law, including the right to health, right to life, respect for human dignity and the principle of non-discrimination, to recognise these claims.

The consequences of these developments have been manifold. They could be seen as a proof of the progressing horizontal effect of human rights and a simple appropriation of the rights discourse by the private sector. At the same time, however, these disputes have highlighted the mutual interdependence between the global health system and nation states (domestic health care systems). For instance, it could be argued that the global health system — now seen as an expression of global social justice — has strengthened the nation state, legitimising its legal claims to access to generic drugs against non-state actors (international corporations) through health rights litigation at the national and supranational level. States used the global health law indirectly to establish equitable access to medicines for their citizens. In this respect, global health actually strengthens the position of the state against the power of market forces. This in turn enables the juridification of global health law, contributing to its strengthening, 
expansion, and increased autonomy. The gradual recognition of health rights has helped stabilise the normative expectations occurring as a result of the threat constituted, at one level by the actual and potential HIV positive status, and at another, by the potential collapse of a health care system. The recognition of rights was possible because of the activism and involvement of national and supranational courts, which indirectly started assuming quasi-legislative and regulatory functions in the area of resource allocation ${ }^{21}$. Health rights litigation in the context of HIV/AIDS illustrates the claims according to which "global interactions in medicine, art, science, etc, ...borrow from international human rights law a skeletal set of principles to organize their exchanges, and, even where specific regulations have not been drafted, the reference to rights means that different functional sectors of global society can produce normative constructs to control and temporally to organize their operations. (...) In the supra- or transnational arena, rights promote the formation of institutions able to apply power in highly abstracted fashion, despite their basic lack of social centration and their weak external support" ${ }^{\text {"22 }}$. This has been true also of the most recent developments in the area of global health.

\subsubsection{Biomedical Revolution and Global Health Law-An Unlikely Connection?}

The third constitutional moment has occurred more recently with the biotechnological revolution in medicine. In 2003, Teubner noted that a global health system constitution was being formed in the heated internal and external scientific debates about embryo research and reproductive medicine [91]. However, 10 years later this argument does not seem sufficiently accurate and should be extended to other aspects of biomedicine. The communication and institutionalisation appearing in the area of reproductive medicine, genetics, genomics, neuroscience, and other parts of biomedicine are, despite the abundance of soft law, the clearest demonstration of constitutionalising tendencies in global health, because the legal norms created in this subfield are again assuming the dual function of its self-foundation and self-limitation. But of course, as previously mentioned and predicted, they are by no means homogeneous or harmonious.

In 1978, the first test-tube baby was born, marking the beginning of a new era in reproductive medicine transforming assisted reproduction techniques and embryo research. As a result of this progress the concept of a family has been significantly redefined. Later on prenatal and preimplantation genetic diagnosis shed a new light on the discussions about eugenics. In 1990, when the Human Genome Project (HGP) was launched, scientists were expected to read "the book of life" [92]. On the one hand, there was the promise of "a cornucopia of new drugs" and "personalised medicine" [93]. On the other hand, "[ $[\mathrm{t}]$ here was the frisson of fear that a genetic helotry would be created, doomed by its

21 The recognition of the role of the judiciary (especially domestic constitutional courts and regional human rights courts) in the process of constitutionalisation may cast some doubt over the whole concept of societal constitutionalism, because it acknowledges that transnational law and sectorial constitutions are developing through the expansion of the public rather than the private sphere. An alternative interpretation would be that transnational constitutions are established through a dialectic involvement of both, public and private law. These issues exceed the scope of this paper and will be discussed elsewhere.

22 See [90]. In making this point, Thornhill comes close to acknowledging the observations made by Teubner. The slow yet gradual recognition of the right to health at international and national level in a way which strengthens not only the global health system, but also the political power of the state might undermine Teubner's claims about the complete separation of the political sphere from other global societal constitutions. 
DNA to second-class health care, education and employment" [93]. Inevitably, such conceptualizations, based on deterministic and reductionist assumptions, raised significant human rights concerns. Finding the right balance between human dignity, privacy, autonomy, personhood, identity, freedom of research, and interests of society and the state has proven to be one of the most difficult tasks for lawyers and policy makers alike [94-102]. Twenty years after the launch of the Human Genome Project, advances in genomics that resulted from this research, including DNA collections, direct-to-consumer genetic tests, and systems biology are slowly becoming a part of our everyday life not only at the individual or state level, but also transnationally/globally. Interdisciplinary research collaborations create extremely complex infrastructures for the collection, aggregation, and processing of samples and data ${ }^{23}$. Biobanks are established worldwide ${ }^{24}$. What is more, through private companies [104] providing genetic testing for over 100 traits, diseases and DNA ancestry ${ }^{25}$, genomic sequence information combined with other data sources is freely available on the Web, to people who are not subject to safeguards and professional codes of conduct ${ }^{26}$. The area of direct-to-consumer genetic testing available online remains almost unregulated. These developments exacerbate the difficulties with regard to privacy, autonomy, dignity, and discrimination. Such growth acceleration of the two highly intertwined regimes - science and medicine - has been perceived as excessive and even pathological. Events such as the cloning of "Dolly the Sheep", the whole human genome sequencing, the creation of the first synthetic organism (Craig Venter's "protocell"27), and most recently gene and genome editing [108] instigated heated debates about the limits of science and the essence of humanity. It is here that the conflict between technological acceleration and the increasing scarcity of time may be most openly experienced [109]. This created an acute sense of a crisis in the public view and - "one minute before midnight" - triggered protests against uncontrolled expansion and calls for self-limitation.

All the documents concerning genetics and biomedicine, in particular the Oviedo Convention 1997 with its additional protocols and the UN and UNESCO Declarations $(1997,2003,2005)^{28}$, complemented by a growing body of national laws [110-113] represent an attempt to introduce rules restraining the centrifugal tendencies of the biomedical subarea of the global health system. This attempt includes the search for appropriate scientific and medical equivalents of traditionally state-related human rights. This is how concepts such as prohibition of genetic discrimination, the right to genetic privacy, the right to reproductive autonomy, the right to biological origins, and the right to die in dignity have been coined. These rights are not clearly and unequivocally directed against the totalizing tendencies of the political power of the state. Rather they are called upon to set boundaries and to protect the individual's mental

23 e.g., Human Genome Project, HapMap Project, 1000 Genomes Project, European Genotype Archive.

24 The term 'biobank' is controversial because it may imply commercial nature of the database or a repository. However, it is used here as it seems the most commonly employed by regulators and legal scholars. See: [103].

25 Those companies use genotyping and sequencing of the human genome. U.S. National Library of Medicine. See [105].

26 For analysis see: [106].

27 A synthetic "protocell" is an artificial cell-like particle presenting membrane receptors in a biomimetic manner. See also: [107].

28 These acts, especially the UNESCO Declaration on Human Genome and Human Rights (1997) and the UN Declaration on Reproductive Cloning (2005) are sometimes seen as emerging international customary law, although, these claims seem controversial. Despite common practice of state actors, there still seem to be little evidence that either of the declarations has actually affected the opinion juris of the international community. 
and bodily integrity against the expansive tendencies of social institutions (e.g., knowledge, medicine, technology). Therefore, in order to make their protection effective, attempts are made to readjust them to the rationality and normativity of the subsystem. Of course, it is equally possible that this process of redefinition of human rights is primarily orientated at the reduction of intrusions of other actors and competing domains [114], thus strengthening and giving preponderance to the global health law regime.

Similarly, debates about the moral and legal status of the human embryo have led in some countries to stark state interventions with regard to reproductive medicine and embryo research ${ }^{29}$. However, the effects of these debates at the global level have been different in comparison with genetics. Apart from a few provisions on embryo research in the Oviedo Convention 1997, and the guidelines issued by the European Society of Reproduction and Embryology (ESHRE) ${ }^{30}$ [117], there are hardly any regulations at all. How then, in light of this latency, is it possible to argue that constitutionalisation is taking place also in this area? Here, it is perhaps helpful to highlight the fact that legal issues arising in the context of reproductive medicine belong primarily to the sphere of private law (doctor-patient relationship, disputes between gamete donors, surrogate mothers and infertile couples, etc.). Constitutional norms play secondary role and if they are further extended or strengthened, they develop incrementally remaining embedded in the ensemble of legal norms, forming the constitution in long concealed evolutionary processes. In a nation state, as well as on a global scale, they also exist latently and are peculiarly invisible. According to Teubner, law reconstructs fundamental principles of the functional regime as legal principles and fleshes them out in individual constitutional norms ([33], p. 112). What seems to be suggested here is that the emergence of constitutional law is a process that involves the depiction of certain inherent regime-specific principles as constitutional (which later also become criteria for deciding which legal rules will gain a constitutional status). Such substantive constitutional principles varying accordingly to historical context could occur as: property, contract, competition, social market economy, and ecological sustainability [33]. Without such substantive elements, the constitution would be not much more than a collection of procedures. In global health law, we could argue that values such as human dignity, autonomy, right to health, and health equality, procedural justice, and proportionality do form the basis for the development of constitutional values.

Recent comparative studies of health rights litigation identified growing congruence between health law principles and practices across the world stemming from a cross-cultural imitation between legal systems experiencing similar processes of legal, political and economic transition $[80,81,118]$. Commonalities and important paradigm changes can be observed even in areas so resilient to harmonisation as abortion law. On of such changes in noticeable liberalization of constitutional reproductive rights in Europe, where, as Siegel points out, "[a]fter decades of conflict, a constitutional framework is emerging [...] that allows legislators to vindicate the duty to protect unborn life by providing women dissuasive counselling and the ability to make their own decisions about abortion" [119]. At the same time, however, this intense process of juridification is accompanied by the bifurcation of different forms of

29 e.g., German Act for Protection of Embryos (Embryonenschutzgesetz-ESchG) of 13th December 1990 (BGB1. I S. 2746, as amended in 2001, BGB1. I S. 2702, 2705); English Human Fertilisation and Embryology Act 1990 (amended by the HFEAct 2008); Spanish Law 14/2006 of 26 May 2006 on Techniques of Assisted Reproduction (BOE, 282,24 November 2006 and BOE 284, 26 November 2006) and Law 14/2007 of 3 July 2007 on Biomedical Research (BOE 4 July 2007), etc. For comparative analysis of laws in the EU see: [115].

30 For a list of guidelines issued by ESHRE, see [116]. 
legality and the perpetual tensions between them. The discrepancies between formal and informal rules, between law and other norms, and/or between law and medical practice, which occur in different parts of the world, have the potential to create a situation where already restrictive abortion laws are interpreted in a way that denies women access to the most basic abortion healthcare services guaranteed by law [120]. This might be the reason why human rights and constitutional courts have focused on procedural justice, ensuring that appropriate procedures are established and accepted that guarantee the full realisation of the existing material rights to legal termination. As noticed by Erdman in respect of the European Court of Human Rights: by turning to positive obligations and to procedural rights, the European Court seeks to work through rather than against the state. It seeks to engender change by drawing on the strength of democratic forces within and by acting with rights- protecting institutions of the state, to keep the state at the centre of the system, even while seeking to transform it [121]. Similarly, decisions of the Inter-American Court of Human Rights (IACtHR) in cases such as K.L. v Peru ${ }^{31}$, L.C. v Peru $^{32}$, L.M.R. v Argentina ${ }^{33}$, and Paulina Ramirez Jacinto $v$ Mexico $^{34}$, confirmed and further developed women's right to access legal abortions ${ }^{35}$. This has been also recently accompanied by another case, in which the right to access assisted reproduction services has been successfully argued with reference to both anti-discrimination and disability frameworks ${ }^{36}$. Similarly, at the national level, the Colombian and Argentine Supreme Courts have led the way in liberalising abortion laws by reference to the right to health (care), the right to life, and/or the right to personality, guaranteed by the recently adopted or amended constitutions [124].

Seen in this light, the recognition of constitutional norms might paradoxically be easier. We might find that they are hidden in particular treaty provisions, national constitutions and court decisions, codes of practice, or even research agreements and consent forms. Hence, the main task of medical law scholars and policy-makers could be not to insist on further hierarchical codification, but to start "revealing" those constitutional norms hidden and concealed in transnational medical practice. Consequently, constitutional status could be ascribed to rules such as, the respect of human life in all stages of its development, the duty to obtain informed consent before medical interventions, the obligation to seek approval of an ethics committee before medical research, the prohibition of human reproductive cloning or any modification in the genome of the descendants ${ }^{37}$, or the currently developing principles of data sharing. It has been, therefore, argued that the effects of these recent developments in life sciences on legal institutions such as personhood, rights, citizenship, and legitimacy, have been so profound that

31 K.L. v Peru, CCPR/C/85/D/1153/2003 (3 November 2005) (HRC).

32 L.C. v. Peru, UN Doc. CEDAW/C/50/D/22/2009 (4 November 2011).

33 VDA (on behalf of LMR) v Argentina, Merits, Communication No 1608/2007, UN Doc CCPR/C/101/D/1608/2007, IHRL 157 (UNHRC 2011), (29 March 2011), Human Rights Committee [UNHRC].

34 Paulina del Carmen Ramírez Jacinto v. Mexico, Case 161-02, Report No. 21/07, Inter-Am. C.H.R., OEA/Ser.L/V/ II.130 Doc. 22, rev. 1 (2007).

35 See [122]. A more skeptical view is presented in [123].

36 Artavia Murillo et al. v. Costa Rica, Judgment, Inter-Am. Ct. H. R. (ser. C) No. 257 (November 28 2012). María Mamérita Mestanza Chávez v. Perú is a precedent for identifying discrimination as being a basis for women's reproductive rights violations.

37 Classifying the norm prohibiting human reproductive cloning as constitutional does not contradict the earlier statement that such a ban does not fulfil the criteria of customary international law. 
they have redrafted established boundaries between science and law, and state and society. They have redefined constitutional frameworks as they have radically restructured state-society relations. They are latent in the sense that to date they have not been incorporated in any national or global constitutional texts. Nevertheless, it is arguable that these redefined rights and principles can acquire constitutional status, especially that they will be followed as binding by the different global players and will form the basis of their actions and transnational agreements (e.g., prohibition of commercialisation of human body parts or surrogacy agreements).

This conclusion is strengthened, if we adopt a functional vision of (constitutional) law and accept that that contractual rule-making and intra-organizational norm production is not necessarily only delegated law-making, which requires recognition by the official legal order. We have to accept that sanction is losing the place it once held as the central concept for the definition of law and legal validity - for the delineation of the legal from the social and the global from the national [125]. Norms predominantly belong to soft law and take the form of declarations, guidelines, codes of practice, committees' decisions, public-private partnership programmes and commercial, private law contracts and agreements. This decentralized and non-harmonized body of norms is further complemented by other forms of governance, such as standardization through regulations and data sharing. This softness should not be seen as a deficiency, but as a typical characteristic of global law, an alternative to more formal sets of law [126,127], which provides for the possibility of compromise in terms of cost-effectiveness, pluralism and flexibility [128]. This vision sounds very appealing as it allows the domain of global health law to include all health programmes, agendas and global partnerships, as well as (health care) professional codes of practice. It enables a theorisation of global health law as a societal autonomous regime, a transnational regulatory regime, a functional order, or a global fragment. However, it is not sufficient in itself to establish whether we are witnessing the emergence of a global health constitution. For this further criteria need to be fulfilled. Their identification within the global health regime proves to be more difficult and problematic.

\subsection{Reflexive Mechanism in Global Health Constitution}

According to Teubner a societal constitution requires institutions to assure the existence of a variety of "reflection centres" that would enable and maintain the accountability of regime's institutions. Global health constitutional norms seem to guarantee the "possibility of dissent" [129] in health, through which the "organised-professionalised sphere" of highly rationalised decision-making can be challenged by a "spontaneous sphere" ([33], p. 91) The latter is created through ethics committees, an environment supporting "whistle-blowers", patient or religious groups and civil society organisations, expert and non-expert involvement, but also through competition in research (allowing for different views to be voiced), and pluralisation of research funding institutions. The main aim of this involvement of various stakeholders is to exert pressures on the organised-professional sphere in light of the insufficiency of the law. As we already mentioned, legal sanctions are not an effective mechanism to impose limitation on a functional regime. Teubner argues that these learning processes should be induced by for instance expert knowledge or political power. This is controversial in light of the powerful critique of the role of the expert in the process of legalisation, although it seems that what Teubner has in mind is predominantly the simple transgression and mutual irritations of different systems. 
Through constant impulses - derived from public consultations, patient lobbying, ethics committees' assessments, BMA guidelines, WHO opinions, OECD recommendations-societal expectations are being communicated to the system, and as a result of political and societal pressures eventually transposed into hard law. A perfect example of such learning pressures seems to be the debate and legislative process concerning embryo research. Advances in science and their application in medicine sparked public imagination and raised fears. The scientific discourse (and methodology) providing a biological definition of the embryo was insufficient to accomplish the autonomy of the subsystem. The spontaneous sphere embodied in public opinion and various organisations of civil society (patient and religious groups) fed their normative expectations into the system through the communication and work of special expert committees (the Warnock Committee or the German Parliamentary Committee), which made their recommendations. As a result of a long and complex process the principle of respect for human life and some restriction of embryo research have made it to the arena of hard law. Using a different vocabulary it could be argued that this aspect of societal constitutions describes the need for democratic nature of the juridification and constitutionalisation of the regime. Seen from this perspective, the existence of reflexive (and in this instance legitimising) mechanisms in global health system is more doubtful. The lack of real and sufficient involvement of NGOs in the negotiations preceding the Framework Convention of Tobacco Control constituted a major point of contention ([44], p. 69). Similarly, it could be argued that some laws in the area of genetic testing or reproductive medicine have been imposed on the health care professional or/and against public opinion. On the other hand, some rules (e.g., in the Oviedo Convention, UNESCO Declarations) promote public discussions and appropriate consultation with regard to fundamental questions raised by the developments of biology and medicine ${ }^{38}$.

Criteria for the constitutionality of norms require finding genuine constitutional processes and structures in the realm of global health. They constitute a return to the concept of self-referential reproduction of the legal system rooted in systems theory [6]. Although law plays a merely supporting role in societal constitutionalisation (as it is a primarily social process), it is indispensable if we want to speak about "constitutions in the strict sense" [33]. The importance of law is also recognised by other international lawyers, such as Jan Klabbers, who claims that "...if the label 'constitutional' is to have any meaning beyond rhetorical, it stands for placing a premium on law, over power, but also over other normative orders" [130]. It needs to be remembered that constitutionalisation entails something else than "legalization", understood as an increasing number of treaties, courts and tribunals; it is the emergence, creation, and identification of constitution-like elements in an order ([33], p. 8). Reflexive mechanism, i.e., "second level" rules, of the societal sectors must be coupled with reflexive mechanism of the law. Secondary legal norms "prescribe how the identification, setting, amendment and regulation of competences for the issuing and delegating of primary norms are to occur" ([33], p. 106). Autonomous regimes produce their own procedural norms on law-making, law-recognition, and legal sanctions. Both those elements must be present in a societal constitution. Secondary rule-making in law is combined with defining fundamental rationality principles in an autonomous social sphere. It is argued here that this is the aspect missing from the regulation of global health care. There are still no visible and clear rules defining authority, competences, and mechanisms for the global health law-making.

38 Art. 28 Convention on Human Rights and Biomedicine 4 April 1997 (ETS 164). 
More importantly, as mentioned earlier, global health law lacks a common legal point of reference to appeal to for resolving disagreements or mediating authority to the crowded global health landscape. It is uncertain how violations should be handled, and how third parties should be included. In light of the great internal diversity, heterogeneity, and lack of synchronised development of different subfields of global health the lack of secondary rules make the self-constitutionalisation of global health doubtful. Finally, the elements that are most obviously absent from the global health constitution are those constitutional structures and institutions that help decide which norms and decisions reached in the system are constitutional and which are not, and how to distinguish between constitutional and ordinary law. The distinction between ordinary law and constitutional law remains blurred.

\section{Conclusions}

This paper had several aims. First, it was an attempt to build a conceptual framework of global health law by combining constitutional theory, and international law together with medical and public health law. A normative vision of global health law could potentially be perceived as an instrument enabling the less risk-susceptible operation of the system in the future. It could also provide a framework for a more comprehensive analysis and meta-analysis of its developments. The underlying and primary reason for this study is linked to the difficulties that arise in all areas of global health governance today, starting from the lack of leadership and coherence, and finishing with the lack of equality and justice. The analysis revealed interesting misconceptions about the area of global health, as well as hidden mechanisms and characteristics that need reconceptualization. First of all, it showed that the reluctance of medical, constitutional, and international law theorists to engage with each other's discourses is misguided as it stems from a rigid understanding of the concept of law that does not take into account the growing body of transnational rules of a non-state provenience. It is also harmful, because it hinders a more coherent development of global health law and consequently the achievement of global health goals. Global health system does not fit squarely either into the traditional concepts of constitutionalism and international law. However, by excluding this area from their analysis, constitutionalists and international lawyers deprive themselves of the chance to provide a truly comprehensive analysis of the harsh realities of global law and subsequently the possibility to enrich the constitutionalisation debate.

Second and crucially, the article aimed to examine whether and, if so, to what extent, the system of global health law is undergoing a process of constitutionalisation. The paper used Teubner's concept of societal constitutionalism as a point of reference in the discussion, because of its potential to conceptualise the developments taking place within the system of global health law. The study has shown that a global health law constitution is slowly emerging from a complex and multicentric process of juridification, punctuated by several constitutional moments. However, constitutionalisation has not yet reached the density required to achieve the right balance between autonomy of the system and responsibility for its environment. An astonishing observation followed. Namely, that the most recent constitutional moment occurred in the area of biomedical law, positioned at the intersection of science and medicine. It is surprising because the technological developments are so recent (whereas the constitutionalisation is traditionally conceptualised as an old event of mature orders), but most importantly because prima facie, global biomedical law (in the sense of binding law) is difficult to 
identify, especially in the field of reproductive medicine and research. Here too, an important discovery has been made. A closer look into this issue reveals that constitutional norms are not captured in one document or a treaty, but that they are hidden in different international, national, and transnational acts, including private agreements or decisions of domestic or regional courts. This finding could have potentially significant theoretical and practical consequences. It could be argued that the relevance of constitutional and human rights courts in the development of global health constitutional principles casts some doubt over Teubner's claims that the creation of transnational law now falls primarily within the domain of private actors and adjudicative bodies. It seems to indicate that transnational law formation is a process driven by a complex correlation between the private and the public sphere. This finding, could in turn redirect the efforts towards attempts to identify and empirically construct legal norms within the system of global health. This analysis and construction of global health law might be one of the most important tasks for future lawyers and policy-makers in the whole area of global health governance. The constructivist approach is based on the assumption that despite the transformation of the concept of law at the global level, it is still possible to distinguish between law and non-law, and that law retains its creative function to influence policy changes (e.g., access to treatment, legality of embryo research). At the same time, it recognises that "law is also a set of conceptual categories and schema that help construct, compose, communicate, and interpret social relations' [131]. Therefore, it acknowledges that the meaning of law as a social institution could be understood not only by examining its aims and effects, but also by studying the ways it is actually experienced and understood in the life-world, and used in the everyday life of ordinary people. Thus, future research should aim to evaluate the emergence of the GHL system by analysing the collective construction of legality, i.e., how forms of consciousness combine to constitute ideological or hegemonic legality [132]. The findings of such research should then be evaluated against the background of different theories of transnational law (including those proposed by Kingsbury, Thornhill, and Walker) to reveal any potential discrepancies between theory and practice. This approach provides a foundation for positive social science assessment of the causes and consequences of global health law phenomena, and for philosophical and political normative assessments of which interests are served and disserved, and what the implications might be in relation to various conceptions of justice ([62], p. 24).

Finally, with regard to practical consequences, the analysis has shown that what might be obstructing or delaying the achievement of systemic autonomy of global health law is not so much the lack of legalisation, but the insufficient development of constitutional processes and structures. The creation of "secondary rules" that show how to identify the foci of decision-making in a particular situation and moment in time could indirectly contribute to the solution of two difficult problems in the area of global health, namely legitimacy and effectiveness. Creation of institutional structures that would help resolve conflicts between rules and different organisational and professional rationales rather than adoption of more primary rules and principles in declarations and treaties should be the next fundamental goal for the global health governance. This could be achieved by focusing on bottom-up processes of global health law formation, although attempts of global codification and treaty formation do not need to be seen as obstacles, but complementary to this process. However, according to the systems-theoretical approach they should not be expected to bring unity or stability. Of course, such a conclusion is hardly satisfactory. Teubner does not give us the answer to the crucial question, of "how exactly?" we are to achieve the full formation of a societal constitution. Following systems theory, we can suspect that the 
answer would be to open communication channels and enhance platforms of communications. At the same time, it is important to remember that more communication does not necessarily bring unity or even harmonisation; it can merely help reveal the processes that are taking place within the regime. Nevertheless, such communication could strengthen the position of global health in the global arena. As aptly noted by Mireille Delmas-Marty, "the problem is that dialogue is not enough. It can pave the way towards legal approximation, but cannot build it, and it doesn't resolve the issue of pluralism's limits" ([55], p. 51). What she proposes is an image of "orderly clouds", representing the concept of pluralist harmonisation that respects each part and enables their harmonious expression. It is to be achieved by various means, such as cross-reference, harmonisation through the doctrine of margin of appreciation, hybridisation through common grammar (guiding meta-principles), and most importantly "polychrony" as a means of dealing with the lack of synchronisation between states ([89], pp. 149-50) (and perhaps subareas within regimes). "Ordering pluralism is the art of blending rhythms and combining speeds as precisely as possible - here again, adjusting - to the energy and interia specific to each society. (...) Finding the most well-adapted breaks and accelerations for our societal chariots would prove the wisdom of good governance" ([89], p. 54). This temporal approach to constitutionalisation might complement and support the accomplishment of the responsible self-foundation of the global health law.

\section{Conflicts of Interest}

The author declares no conflict of interest.

\section{References and Notes}

1. Rowson, Mike, Chris Willott, Rob Hughes, Arti Maini, Sophie Martin, J. Jaime Miranda, Vicki Pollit, Abi Smith, Rae Wake, and John S. Yudkin. "Conceptualising Global Health: Theoretical Issues and their Relevance for Teaching." Globalization and Health 8 (2012): 36.

2. Gostin, Lawrence O. Public Health Law: Power, Duty, Restraint. Berkley: University of California Press, 2008, pp. 3-4.

3. Koplan, Jeffrey P., T. Christopher Bond, Michael H. Merson, K. Srinath Reddy, Mario Henry Rodriguez, Nelson K. Sewankambo, Judith N. Wasserheit, and Consortium of Universities for Global Health Executive Board. "Towards a common definition of global health." The Lancet 373 (2009): 1993-95.

4. Fidler, David P. "Challenges to Global Health Governance." Council of Foreign Relations Working Paper, Council of Foreign Relations, New York, NY, USA, May 2010. Available online: http://www.cfr.org/global-governance/challenges-global-health-governance/p22202 (accessed on 16 December 2015).

5. Fidler, David. “Architecture amidst Anarchy: Global Health's Quest for Governance.” 1 Global Health Governance 1 (2007): 1-17.

6. Luhmann, Niklas. "Law as a Social System.” Northwestern University Law Review 83 (1988): 136.

7. Aginam, Obijiofor. Global Health Governance: International Law and Public Health in a Divided World. Toronto: University of Toronto Press Inc., 2005.

8. Gostin, Lawrence O., and Allyn L. Taylor. "Global Health Law: A Definition and Grand Challenges." Public Health Ethics 1 (2008): 53-63. 
9. Ruger, Jennifer Prah. "Normative Foundations of Global Health Law." Georgetown Law Journal 96 (2008): 423-43.

10. Bennett, Belinda. Health Law's Kaleidoscope: Health Law Rights in a Global Age. Aldershof: Ashgate, 2008.

11. Youde, Jeremy R. Global Health Governance. London: Polity Press, 2012.

12. Gostin, Lawrence O., and Eric A. Friedman. "Global Health Justice: Towards a Framework Convention on Global Health-A Transformative Agenda for Global Governance for Health." Yale Journal of Health Policy, Law, and Ethics 13 (2013): 1-75.

13. Daniels, Norman. Just Health. Cambridge: Cambridge University Press, 2008, p. 145.

14. WHO. "World Health Statistics Report.". 2012. Available online: http://apps.who.int/iris/ bitstream/10665/44844/1/9789241564441_eng.pdf?ua=1 (accessed on 16 December 2015).

15. Buse, Kent, and Gill Walt. "Global public_-Private health partnerships: Part I—A new development in health?” Bulletin of the World Health Organization 78 (2000): 549-61.

16. Buse, Kent, and Gill Walt. "Global public_-Private health partnerships: Part II—What are the issues for global governance?" Bulletin of the World Health Organization 78 (2000): 699-709.

17. Chen, Lincoln, Timothy Evans, Sudhir Anand, Jo Ivey Boufford, Hilary Brown, Mushtaque Chowdhury, Marcos Cueto, Lola Dare, Gilles Dussault, Gijs Elzinga, et al. "Human resources for health: Overcoming the crisis.” The Lancet 364 (2004): 1984-90.

18. Kickbusch, Ilona. "In search of the public health paradigm for the 21 st century: The political dimensions of public health." Portuguese Journal of Public Health (2009): 11-19.

19. Gostin, Lawrence O., and Anna E. Roberts. "Forced Migration, The Human Face of a Health Crisis." The Journal of the American Medical Association 314 (2015): 2125-26.

20. Teubner, Gunther, ed. Global Law without a State. Dartmouth: Aldershot, 1997, pp. 3-28.

21. Krisch, Nico, and Benedict Kingsbury. "Introduction: Global Governance and Global Administrative Law in the International Legal Order.” The European Journal of International Law 17 (2006): 1-13.

22. Jessup, Philip Caryl. Transnational Law. New Heaven: Yale University Press, 1956, p. 2.

23. Zumbansen, Peer C. "Transnational comparisons: Theory and practice of comparative law as a critique of global governance." In Practice and Theory in Comparative Law. Edited by Maurice Adams and Jacco Bomhoff. Cambridge: Cambridge University Press, 2012, p. 189.

24. Zumbansen, Peer. "Neither 'public' nor 'private'." In Beyond Territoriality: Transnational Legal Authority in an Age of Globalization. Edited by Gunther Handl, Joachim Zekoll and Peer Zumbansen. Leiden and Boston: Martinus Nijhoff, 2012.

25. Kjaer, Poul F., Gunther Teubner, and Alberto Febbrajo, eds. The Financial Crisis in Constitutional Perspective: The Dark Side of Functional Differentiation. Oxford: Hart Publishing, 2011.

26. Joerges, Christian, and Ernst-Ulrich Petersmann. Constitutionalism, Multilevel Trade Governance and Social Regulation. Oxford: Hart Publishing, 2006.

27. Joerges, Christian, Poul F. Kjaer, and Tommi Ralli. “A New Type of Conflicts Law as Constitutional Form in the Postnational Constellation.” Transnational Legal Theory 2 (2011): 153-285.

28. Kjaer, Poul F. "The Concept of the Political in the Concept of Transnational Constitutionalism: A Sociological Perspective." In After Globalization -New Patterns of Conflict and their Sociological and Legal Reconstruction. Oslo: University of Oslo, 2011, pp. 285-321. 
29. Fried, Linda P., Margaret E. Bentley, Pierre Buekens, Donald S. Burke, Julio J. Frenk, Michael J. Klag, and Harrison C. Spencer. "Global Health is Public Health.” The Lancet 375 (2010): 535-37.

30. Walker, Neil. “The Idea of Constitutional Pluralism.” Modern Law Review 65 (2002): 317-59.

31. Michaels, Ralf. "Global Legal Pluralism." Annual Review of Law and Social Science 5 (2009): 243-62.

32. Walker, Neil. "Beyond Boundary Disputes and Basic Grids: Mapping the Global Disorder of Normative Orders." International Journal of Constitutional Law 6 (2008): 373-96.

33. Teubner, Gunther. Constitutional Fragments. Societal Constitutionalism and Globalisation. Oxford: Oxford University Press, 2012.

34. Anderson, Gavin W. "Beyond Constitutionalism beyond the State." Journal of Law and Society 39 (2012): 359-83.

35. Peters, Anne. "Compensatory Constitutionalism: The Function and Potential of Fundamental International Norms and Structures." Leiden Journal of International Law 19 (2006): 579-610.

36. Delmas-Marty, Mireille, and Marie-Laure Izorche. "Marge nationale d'appréciation et internationalisation du droit. Réflexions sur la validité formelle d'un droit commun pluraliste." Revue Internationale de Droit Comparé 52 (2000): 753-80.

37. Cueto, Marcos. "The ORIGINS of Primary Health Care and Selective Primary Health Care." American Journal of Public Health 94 (2004): 1864-74.

38. Sridhar, Devi. "Seven challenges in international development assistance for health and ways forward." Journal of Law, Medicine and Ethics 38 (2010): 459-69.

39. Pfeiffer, James, and Rachel Chapman. "Chapman, Anthropological Perspectives on Structural Adjustment and Public Health.” Annual Review of Anthropology 39 (2010): 149-65.

40. Labonté, Ronald, Katia Mohindra, and Ted Schrecker. "The growing impact of globalisation for health and public practice." Annual Review of Public Health 32 (2011): 263.

41. Fidler, David P., and Lawrence O. Gostin. "The New International Health Regulations: An Historic Development for International Law and Public Health." Journal of Medicine and Ethics 34 (2006): 85-94.

42. World Health Organization. "WHO Framework Convention on Tobacco Control." Available online: http://whqlibdoc.who.int/publications/2003/9241591013.pdf (accessed on 16 December 2015).

43. Fidler, David P. "The Future of the World Health Organization: What Role for International Law?" Vanderbilt Journal of Transnational Law 31 (1998): 1079.

44. Meier, Benjamin Mason, and Donna Shelley. "The Fourth Pillar of the Framework Convention on Tobacco Control: Harm Reduction and the International Human Right to Health." Public Health Report 121 (2006): 494-500.

45. Kuppuswamy, Chamundeeswari. The International Legal Governance of the Human Genome. London: Routledge, 2009.

46. WHO, and UNICEF. "International Conference on Primary Health Care." Paper presented at Declaration of Alma-Ata, Alma-Ata, Kazakhstan, 6-12 September 1978. Available online: http://www.who.int/social_determinants/tools/multimedia/alma_ata/en/ (accessed on 16 December 2015).

47. UNESCO. “About the Bioethics Programme.” Available online: http://www.unesco.org/new/en/ social-and-human-sciences/themes/bioethics/about-bioethics/ (accessed on 16 December 2015). 
48. Andorno, Roberto. "Global Bioethics at UNESCO: In Defence of the Universal Declaration of Bioethics and Human Rights.” Journal of Medical Ethics 33 (2007): 150-54.

49. United Nations. "The Right to the Highest Attainable Standard of Health." 2000. Available online: http://www.nesri.org/resources/general-comment-no-14-the-right-to-the-highest-attainable-stand ard-of-health\#sthash.deGP2egv.dpuf (accessed on 16 December 2015).

50. WHO. "Global Code of Practice on the International Recruitment of Health Personnel, Sixty-third World Health Assembly-WHA63.16, May 2010, Document A63/8." 2010. Available online: http://www.who.int/hrh/migration/code/code_en.pdf (accessed on 16 December 2015).

51. Harman, Sophie. Global Health Governance. London: Routledge, 2012.

52. Godal, Tore. "Do We Have the Architecture of Health Aid Right? Increasing Global Aid Effectiveness." Nature Reviews Microbiology 3 (2005): 899-903.

53. Epstein, Paul R., and Greg Guest. "International Architecture for Sustainable Development and Global Health." In Globalization, Health and the Environment: An Integrated Perspective. Edited by Greg Guest. Landham: Altamira Press, 2005, pp. 239-58.

54. Secretary-General. "Uniting for universal access: Towards zero new HIV infections, zero discrimination and zero AIDS-related deaths." Report of the Secretary-General, U.N. Doc A/65/979, March 2011. Available online: http://www.unaids.org/sites/default/files/en/media/ unaids/contentassets/documents/document/2011/20110331_SG_report_en.pdf (accessed on 16 December 2015).

55. Delmas-Marty, Mireille. Ordering pluralism: A Conceptual Framework for Understanding the Transnational Legal World. Bloomsbury: Bloomsbury Publishing, 2009, p. 13.

56. Koskenniemi, Martti, and Päivi Leino. "Fragmentation of international law? Postmodern anxieties." Leiden Journal of International Law 15 (2002): 553-79.

57. International Law Commission. "Study Group on Fragmentation of International Law: Difficulties Arising from the Diversification and Expansion of International Law (A/CN.4/L.702)." Paper presented at 58th session of the International Law Commission, Geneva, Switzerland, 2006. Available online: http://legal.un.org/ilc/guide/1_9.shtml (accessed on 16 December 2015).

58. Koskenniemi, Martti. "Report of the Study Group of the International Law Commission finalized by Martti Koskenniemi (A/CN.4/L.682)." Paper presented at 58th session of the International Law Commission, Geneva, Switzerland, 13 April 2006. Available online: http://legal.un.org/docs/ ?symbol=A/CN.4/L.682 (accessed on 16 December 2015).

59. Pauwelyn, Joost. "Fragmentation of International Law." In Max Planck Encyclopedia of Public International Law. Oxford: Oxford University Press, 2009.

60. Simma, Bruno, and Dirk Pulkowski. "Of Planets and the Universe: Self-Contained Regimes in International Law.” European Journal International Law 17 (2006): 483-529.

61. Foucault, Michel. "The Birth of Biopolitics.” In Essential Works of Foucault 1954-1984. Edited by Paul Rabinow. London: Penguin Books, 2000, vol. 1, pp. 73-85.

62. Kingsbury, Benedict. "The Concept of 'Law' in Global Administrative Law." The European Journal of International Law 20 (2009): 23-57.

63. Walker, Neil. "The EU and the WTO: Constitutionalism in a New Key." In The EU and the WTO: Legal and Constitutional Issues. Edited by Gráinne De Búrca and Joanne Scott. Oxford: Hart Publishing, 2001, p. 33. 
64. Krisch, Nico. Beyond Constitutionalism. The Pluralist Structure of Postnational Law. Oxford: Oxford University Press, 2010, p. 298.

65. Béhague, Dominique P., and Katerini T. Storeng. "Collapsing the Vertical-Horizontal Divide: An Ethnographic Study of Evidence-Based Policymaking in Maternal Health." American Journal of Public Health 98 (2008): 644-49.

66. Harman, Sophie. The World Bank and the HIV/AIDS: Setting a Global Agenda. London: Routledge, 2010.

67. Weindling, Paul. "The Origins of Informed Consent: The International Scientific Commission on Medical War Crimes, and the Nuremberg Code." Bulletin of the History of Medicine 75 (2001): $37-71$.

68. World Medical Association. "Ethical Principles for Medical Research Involving Human Subjects." 1964. Available online: http://www.wma.net/en/30publications/10policies/b3/ (accessed on 16 December 2015).

69. Council for International Organizations of Medical Sciences (CIOMS). "International Ethical Guidelines for Biomedical Research involving human subjects." 2002. Available online: http://www.cioms.ch/publications/layout_guide2002.pdf (accessed on 16 December 2015).

70. CCPR. "General Comment No. 20: Replaces general comment 7concerning prohibition of torture and cruel treatment or punishment (Art. 7). CCPR General Comment No. 20 (General Comments)." 3 October 1992. Available online: http://www.unhchr.ch/tbs/doc.nsf/0/6924291970754969c1256 3ed004c8ae5 (accessed on 16 December 2015).

71. Allen, Charles E. "World Health and World Politics." International Organisation 4 (1950): 27-43.

72. WHO. "Chronicle of the World Health Organization 1." Paper presented at WHO, Geneva, Switzerland, 1947. Available online: http://www.who.int/library/collections/historical/en/index3.html (accessed on 16 December 2015).

73. Ruger, Jennifer Prah, and Derek Yach. "The Global Role of the World Health Organization." Global Health Governance 2 (2008): 1.

74. McColl, Karen. Found more than 40 bilateral donors, 26 UN agencies, 20 global and regional funds, and 19 global-health initiatives. See: McColl, Karen. "Europe told to deliver more aid for health." Lancet 37 (2008): 2072-73.

75. Zuniga, José M., Stephen P. Marks, and Lawrence O. Gostin, eds. Advancing the Human Right to Health. Oxford: OUP, 2013.

76. Harrington, John, Maria Stuttaford, eds. Global Health and Human Rights. London and New York: Routledge, 2011.

77. Wolff, Jonathan. The Human Right to Health. New York and London: W.W Northon and Company, 2012.

78. Murphy, Therese. Health and Human Rights. Oxford: Hart Publishing, 2013.

79. Wolff, Jonathan. "Global Justice and Health: The Basis of the Global Health Duty." In Global Justice and Bioethics. Edited by Millum Joseph. Oxford: Oxford University Press, 2012, pp. 78-101.

80. Yamin, Alicia Ely, Siri Gloppen, Paola Bergallo, and Octavio Luiz Motta Ferraz. Litigating Health Rights: Can Courts Bring More Justice to Health? Harvard: Harvard University Press, 2011.

81. Gauri, Varun, and Daniel M. Brinks, eds. Courting Social Justice: Judicial Enforcement of Social and Economic Rights in the Developing World. Cambridge: Cambridge University Press, 2008. 
82. Ooms, Gorik. "From the global AIDS response towards Global Health?" Discussion paper for the Hélène De Beir Foundation and the International Civil Society Support, Belgium, 2009. Available online: http://www.hdbf.org/?page_id=345\&lang=en (accessed on 16 December 2015).

83. United Nations Development Programme. "Global Commission on HIV and the law booklet." 2011. Available online: http://www.hivlawcommission.org/images/stories/CommissionBookletEnglish-18May2011.pdf (accessed on 16 December 2015).

84. UN General Assembly. "Political Declaration on HIV and AIDS: Intensifying Our Efforts to Eliminate HIV and AIDS.” 8 July 2011. Available online: http://www.unaids.org/en/media/ unaids/contentassets/documents/document/2011/06/20110610_UN_A-RES-65-277_en.pdf(accessed on 16 December 2015).

85. WHO. "Consolidated guidelines on the use of antiretroviral drugs for treating and preventing HIV infection.” 2013. Available online: http://www.who.int/hiv/pub/guidelines/arv2013/en/index.html (accessed on 16 December 2015).

86. The Global Fund. "The Global Fund's Procurement and Supply Management Policies." Available online: http://www.theglobalfund.org/en/activities/psm/ (accessed on 16 December 2015

87. The Global Fund. "The Global Fund's Quality Assurance Policies." Available online: http://www.theglobalfund.org/en/procurement/quality/ (accessed on 16 December 2015).

88. Harrington, John A. “AIDS, Public Health and the Law a Case of Structural Coupling?" European Journal of Health Law 6 (1999): 213-34.

89. England, Roger. “Are we spending too much on HIV?” British Medical Journal 334 (2007): 344.

90. Thornhill, Christopher. "Rights and Constituent Power: A Sociological View of the Global Constitution." Paper presented at the Edinburgh Legal Theory Festival, Edinburgh, UK, 29 May 2013. Available online: http://www.repository.law.indiana.edu/ijgls/vol20/iss2/3/ (accessed on 16 December 2015).

91. Teubner, Gunther. "Globale Zivilverfassungen: Alternativen zur staatszentrierten Verfassungstheorie." Zeitschrift für ausländisches öffentliches Recht und Völkerrecht 63 (2003): 1-28.

92. Kay, Lily E. Who Wrote the Book of Life? The History of the Genetic Code. Redwood City: Stanford University Press, 2000.

93. The Economist. "A special report on the human genome: Biology 2.0." 17 June 2010, Available online: http://www.economist.com/node/16349358 (accessed on 16 December 2015).

94. Dworkin, Ronald. "Playing God: Genes, Clones and Luck." In Sovereign Virtue: The Theory and Practice of Equality. Edited by Ronald Dworkin. Cambridge: Harvard University Press, 2000, pp. 427-52.

95. Spinello, Richard A. "Property rights in genetic information." Ethics and Information Technology 6 (2004): 29-42.

96. Suter, Sonia M. "Whose Genes Are These Anyway?: Familial Conflicts over Access to Genetic Information." Michigan Law Review 91 (1993): 95.

97. Sándor, Judit. "Genetic information: Science, Society and Legal Norms" In Society and Genetic Information. New York and Budapest: Central European University Press, 2003.

98. Bovenberg, Jasper A. Property Rights in Blood, Genes \& Data: Naturally Yours? Leiden and Boston: Martinus Nijhoff Publishers, 2006. 
99. Murray, Thomas H. "Genetic Exceptionalism and Future Diaries: Is Genetic Exceptionalism Different from Other Medical Information?" In Genetic Secrets: Protecting Privacy and Confidentiality in the Genetic Era. Edited by Mark A. Rothstein. New Haven: Yale University Press, 1997.

100. Laurie, Graeme. Genetic Privacy. Challenge to Medico-Legal Norms. Cambridge: Cambridge University Press, 2002.

101. Radetzki, Marcus, Marian Radetzki, and Niklas Juth. Genes and Insurance. Ethical, Legal and Economic Issues. Cambridge: Cambridge University Press, 2003.

102. Thompson, Alison K., and Ruth F. Chadwick, eds. Genetic Information Acquisition, Access and Control. Berlin: Kluwer Academic Publishers, 1999.

103. Cambon-Thomsen, Anne, Clémentine Sallée, Emmanuelle Rial-Sebbag, and Bartha Maria Knoppers. "Populational Genetic Databases: Is a Specific Ethical and Legal Framework Necessary?" GenEdit 3 (2005): 1-13.

104. 23andMe. Available online: https://www.23andme.com/ (accessed on 16 December 2015).

105. Genetics Home Reference. "Genotyping." Available online: http:/ghr.nlm.nih.gov/glossary= genotyping (accessed on 16 December 2015).

106. Church, George, Catherine Heeney, Naomi Hawkins, Jantina de Vries, Paula Boddington, Jane Kaye, Martin Bobrow, and Bruce Weir. "Public access to genome-wide data: Five views on balancing research with privacy and protection." PLoS Genet 5 (2009): e1000665.

107. Badau, Mark, and Emily C. Parke. The Ethics of Protocells: Moral and Social Implications of Creating Life in the Laboratory. Cambridge: MIT Press, 2009.

108. Reardon, Sara. "Global summit reveals divergent views on human gene editing." Nature News, 8 December 2015. Available online: http://www.nature.com/news/global-summit-revealsdivergent-views-on-human-gene-editing-1.18971 (accessed on 16 December 2015).

109. Rosa, Hartmut. "Social Acceleration: Ethical and Political Consequences of a Desynchronized High-Speed Society." Constellations 10 (2003): 3-33.

110. Swiss Science and Technology Council. "The Swiss Federal Law on the Genetic Testing of Humans (Bundesgesetz über genetische Untersuchungen beim Menschen (GUMG).” 2004. Available online: http://www.admin.ch/ch/d/sr/c810_12.html (accessed on 16 December 2015).

111. Author/Organization. "The US Genetic Information Non-discrimination Act (GINA 2008)." Available online: http://homas.loc.gov/cgi-bin/bdquery/z?d110:HR00493 (accessed on 16 December 2015).

112. Buzer. De. "The German human genetic examination act (Gesetz über genetische Untersuchungen bei Menschen (Gendiagnostikgesetz-GenDG).” Available online: http://www.buzer.de/gesetz/ 8967/index.htm (accessed on 16 December 2015).

113. The Portuguese Law no. 12/2005 on personal genetic information and information regarding health Privileged Project. "Privacy in law, ethics and genetic data." Genetic databases and Biobanks by Country. Available online: http://www.privileged.group.shef.ac.uk/projstages/ stage-2-genetic-databases-and-biobanks/genetic-databases-and-biobanks-by-country/portugal (accessed on 16 December 2015).

114. Dilling, Olaf, Martin Herberg, and Gerd Winter, eds. Responsible Business. Self-Governance and Law in Transnational Economic Transactions. Oxford: Hart Publishing, 2008, p. 8. 
115. ESHRE Central Office. "Comparative Analysis of Medically Assisted Reproduction in the EU: Regulation and Technologies.” Final Report, ESHRE Central Office, Grimbergen, Belgium, 2008. Available online: http://ec.europa.eu/health/blood_tissues_organs/docs/study_eshre_en.pdf (accessed on 16 December 2015).

116. European Society of Human Reproduction and Embryology. "Guidelines." Available online: https://www.eshre.eu/Guidelines-and-Legal/Guidelines.aspx (accessed on 16 December 2015).

117. Teubner, Gunther. "The Anonymous Matrix: Human Rights Violations by 'Private' Transnational Actors." The Modern Law Review 69 (2006): 346.

118. Langford, Malcolm. Social Rights Jurisprudence: Emerging Trends in International and Comparative Law. Cambridge: Cambridge University Press, 2008.

119. Siegel, Reva. "The Constitutionalization of Abortion." In Abortion Laws in Transnational Perspective: Cases and Controversies. Edited by Rebecca J. Cook, Joanna N. Erdman and Bernard M. Dickens. Philadelphia: University of Pennsylvania Press, 2014, p. 35.

120. Bergallo, Paola. "The Struggle against Informal Rules on Abortion in Argentina." In Abortion Laws in Transnational Perspective: Cases and Controversies. Edited by Rebecca J. Cook, Joanna N. Erdman and Bernard M. Dickens. Philadelphia: University of Pennsylvania Press, 2014.

121. Erdman, Joanna N. "The Procedural Turn: Abortion at the European Court of Human Rights." In Abortion Laws in Transnational Perspective: Cases and Controversies. Edited by Rebecca J. Cook, Joanna N. Erdman and Bernard M. Dickens. Philadelphia: University of Pennsylvania Press, 2014, p. 141.

122. O'Connell, Ciara. "Litigating reproductive health rights in the inter-American system: What does a winning case look like?" Health and Human Rights 16 (2014): 116-28.

123. Bates, Charlotte. "Abortion and a right to health in international law." Cambridge Journal of International and Comparative Law 2 (2013): 640.

124. Dickens, Bernard M. “The Right to Conscience.” In Abortion Laws in Transnational Perspective: Cases and Controversies. Edited by Rebecca J. Cook, Joanna N. Erdman and Bernard M. Dickens. Philadelphia: University of Pennsylvania Press, 2014.

125. Teubner, Gunther. "Global Bukowina: Legal Pluralism in the World Society." In Global Law without a State. Edited by Gunther Teubner. Aldershot: Dartmouth Publishing, 1997, pp. 3-28.

126. Teubner, Gunther, and Peter Korth. "Two Kinds of Legal Pluralism: Collision of Laws in the Double Fragmentation of World Society." In Regime Interaction in International Law: Facing Fragmentation. Edited by Margaret A. Young. Cambridge: Cambridge University Press, 2012.

127. Goldstein, Judith J., Miles Kahler, Robert O. Keohane, and Anne-Marie Slaughter. "Legalization and World of Politics." International Organization 54 (2000): 385-400.

128. Abbott, Kenneth W., and Duncan Snidal. "Hard and Soft Law in International Governance." International Organization 3 (2000): 421-56.

129. Luhmann, Niklas. "Politische Verfassungen im Kontext des Gesellschaftssystems." Der Staat 12 (1973): 165-82.

130. Klabbers, Jan. "Law-making and constitutionalism." In The Constitutionalization of International Law. Edited by Jan Klabbers, Anne Peters and Geir Ulfstein. Oxford: Oxford University Press, 2009, p. 124. 
131. Silbey, Susan S. “After legal consciousness.” Annual Review of Law and Social Science 1 (2005): 323-68.

132. Merry, Sally Engle, and Susan S. Silbey. "What do plaintiffs want: Re-examining the concept of dispute." The Justice System Journal 9 (1984): 151-78.

(C) 2015 by the author; licensee MDPI, Basel, Switzerland. This article is an open access article distributed under the terms and conditions of the Creative Commons Attribution license (http://creativecommons.org/licenses/by/4.0/). 